International Research Journal of Management, IT \& Social Sciences
Available online at https://sloap.org/journals/index.php/irjmis/
Vol. 8 No. 6, November 2021, pages: 712-719
$\begin{aligned} & \text { ISSN: 2395-7492 } \\ & \text { https://doi.org/10.21744/irjmis.v8n6.1972 }\end{aligned}$

\title{
Processes Aimed at Students to Improve their Learning
}

\author{
Fernando Eduardo Cornejo Rivas a \\ Marilyn Lidia Basurto Pilligua ${ }^{b}$ \\ Jacqueline Aracely Arteaga Guerrero ${ }^{c}$ \\ José Atilio Murillo Moreira ${ }^{\mathrm{d}}$ \\ María José Zambrano Zambrano ${ }^{\mathrm{e}}$
}

Article history:

Submitted: 27 September 2021

Revised: 18 October 2021

Accepted: 05 November 2021

\section{Keywords:}

educators;

knowledge;

learners:

motivation;

techniques;

\begin{abstract}
Nowadays educators are using less frequent activities that motivate students, usually, some teachers often repeat techniques similar to the previous one, and that causes distraction in children. Motivational activities are factors that influence the teaching-learning process, being the fundamental engine to attract attention and have participative children capable of expressing the knowledge acquired in their environment because they like to know, learn. The objective of the work is to investigate the motivation that the teacher has in the teaching-learning process, which opens the student's reflective observation. The study of playful activities was used that offer the ability to internalize knowledge with technological tools where the modality is applied playing I learn, but it does not necessarily have to do with a game itself, but with a phrase. It was obtained as a result that students learn better with recreational activities than with traditional methodology.
\end{abstract}

International research journal of management, IT and social sciences (C) 2021. This is an open access article under the CC BY-NC-ND license (https://creativecommons.org/licenses/by-nc-nd/4.0/).

\section{Corresponding author:}

Fernando Eduardo Cornejo Rivas, Master's in Educational Innovation, Pontificia Universidad Católica del Ecuador, Manabí Headquarters, Portoviejo, Ecuador.

Email address: fcprnejo9991@pucesm.edu.ec

\footnotetext{
Maestría en Innovación Educativa, Pontificia Universidad Católica del Ecuador, Sede Manabí, Portoviejo, Ecuador

b Maestría en Innovación Educativa, Pontificia Universidad Católica del Ecuador, Sede Manabí, Portoviejo, Ecuador c Maestría en Innovación Educativa, Pontificia Universidad Católica del Ecuador, Sede Manabí, Portoviejo, Ecuador d Maestría en Innovación Educativa, Pontificia Universidad Católica del Ecuador, Sede Manabí, Portoviejo, Ecuador Maestría en Innovación Educativa, Pontificia Universidad Católica del Ecuador, Sede Manabí, Portoviejo, Ecuador 


\section{Introduction}

Currently, teachers must apply motivating activities to be able to work with students within the classroom, collectively or individually, and thus be able to signify a greater interest in learning, when they do not respond assertively to the traditional activities of teachers In his teachings, it leads to the fact that knowledge was not learned by everyone in the same way, because not all students learn in the same way, the teacher must generate motivating activities, through various techniques that are appropriate to the subject in which they want to teach. Some educators know how to carry out motivational activities and who develop them with great skill to the students, generating optimal learning, some teachers do not want to update themselves and work in a traditional way which makes it difficult for the knowledge acquired by the students to become more difficult.

In other countries, the importance of motivation that generates significant learning has been identified (Tirado et al., 2013). In the reality that is being lived, it can be distinguished that learning is carried out in a very different way between virtual and face-to-face education where children do not assimilate the respective knowledge that is being imparted by the educator. The education that is being imparted to students should motivate institutions to strive for the application of computer science and communication techniques (ICT), in the teaching and learning processes, since they enhance creativity, flexibility, among other factors that enable the configuration of innovative teaching processes in general, teaching in particular (Portilla Rendón, 2002). Learning theories allow offering knowledge in the teaching process with its advantages and disadvantages according to the point of view of different authors (Castro \& de Castro, 2005). Thus, they allow to base, design, and configure different innovative pedagogical processes mediated by ICT, by the contents, where these have the purpose of responding to the teaching objectives that facilitate a better procedure.

Motivational strategies are teaching and learning processes aimed at improving the educational process of students, where the intervention of the teacher is needed, who is in charge of innovating these. Each person builds their motivation thanks to the appropriation of tools, interacting with the motivation of others, individually and collectively (Tripiana Muñoz, 2016). The student must assume a positive attitude regarding their learning, which will be done with the different motivational alternatives available to the teacher to improve the quality of teaching and make learning meaningful for schoolchildren (Silva Zambrano, 2016). Among the benefits obtained from using a Motivational Activities Manual is to ensure that classes have innovative activities, obtaining children interested in the subject, to continue to learn new and relevant things. It helps the teacher a lot to show that their creativity is a strength at the time of teaching that, together with love, the classes become interesting for the students (Prudente Tomalá, 2015).

Motivation in students has been of great interest for a long time; which is given by the need to know-how, which ones and why or in what way teachers and students act in a given class. In the teaching process, motivation is necessary, it is found within the didactic strategies together with guidance and information, through them the teacher plans and at the end of the process assesses the students to achieve the proposed educational objectives (Vite Ríos, 2016). Strategies must be used that allow the adolescent to adapt to the changes that are generated during the teaching-learning process. Always bearing in mind that there must be a relationship between the previous contents with the new information so that they have an interest in what they are learning, it is also necessary for the teacher to generate a cordial atmosphere within the classroom among classmates, thus achieving better cooperation in the classroom. activities that are developed in class. The important thing would be that the teacher develops strategies according to the level of learning of each student. For this reason, motivational strategies must be established to improve the adaptation of students in the teaching-learning process (Silva Zambrano, 2016). Effective learning implies that the students actively operate in the manipulation of the information to be learned, thinking - acting on it to review it, expand it, assimilate it, organizing cognitive structures. Piaget calls them schemas; Bandura, auto systems; Kelly, personal constructs (Vite Ríos, 2016).

\section{Materials and Methods}

The methodology used is based on qualitative analysis, inductive-deductive that will help the interpretation of the processes to improve learning in students, the basic modality of research is descriptive that will help the scientific support of motivating activities schoolchildren. The exploratory methodology and the bibliographic documentary were used where the different approaches, theories, conceptualizations, and criteria of various authors were known, compared, expanded, deepened, and deduced the different approaches, theories, conceptualizations, and criteria of various authors based on documents, books, publications in reliable scientific databases, among which They host high-

Rivas, F. E. C., Pilligua, M. L. B., Guerrero, J. A. A., Moreira, J. A. M., \& Zambrano, M. J. Z. (2021). Processes aimed at students to improve their learning. International Research Journal of Management, IT and Social Sciences, 8(6), 712-719. https://doi.org/10.21744/irjmis.v8n6.1972 
impact scientific journals that helped enrich the theoretical part of the research work (Oka, 2021; Suhifatullah et al., 2021).

\section{Results and Discussions}

\section{Motivational model motivation}

is a psychological construct used to explain voluntary behavior, when academics implies a desire to perform well in the classroom, this is reflected involuntary behaviors that eventually lead to a testable development. Class attendance is a voluntary behavior, which is combined with others to reflect the level of academic motivation (Anaya-Durand \& Anaya-Huertas, 2010).

According to Pintrich cited by Anaya-Durand \& Anaya-Huertas (2010), he explained the academic motivation in the class in terms of reciprocal interactions between three components:

1) The context of the class

2) The feelings and beliefs of the students about their motivation

3) The observable behaviors of the students.

The first two determine the third: observable behaviors in students. According to Pintrich cited by Anaya-Durand \& Anaya-Huertas (2010), the observable behaviors that reflect the level of academic motivation are, in turn, of three different classes as shown in figure 1.

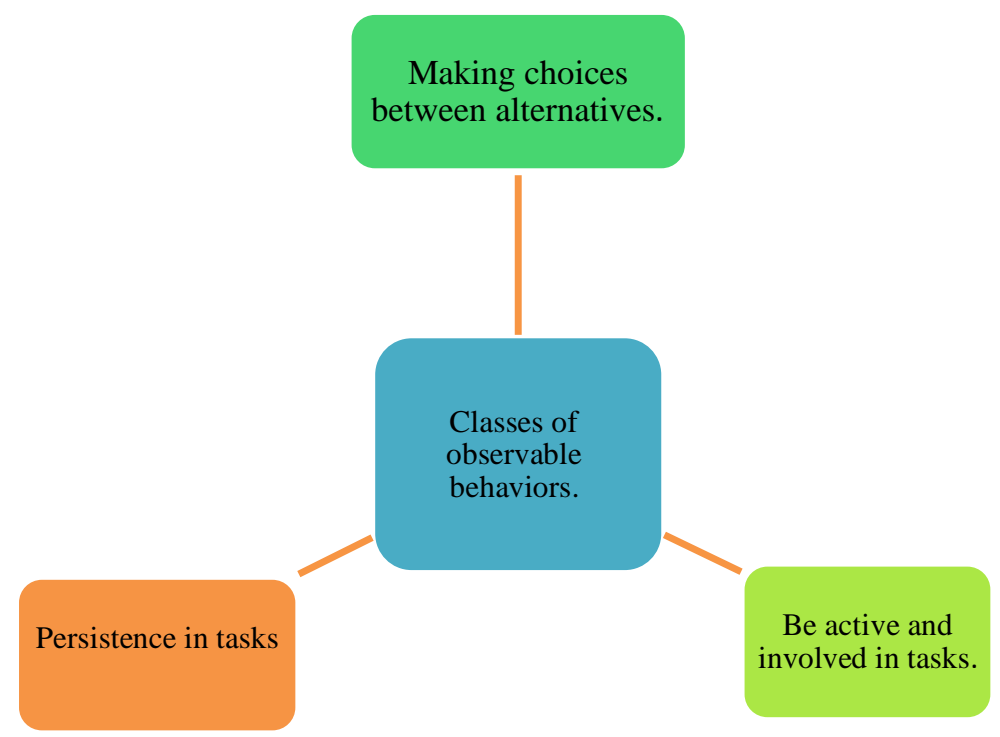

Figure 1. Classes of observable behaviors

Source: (Anaya-Durand \& Anaya-Huertas, 2010)

As can be seen, it is denoted in having persistence and being involved in tasks, students make many choices: they decide to take a course, work on a task assigned, attend a class session, or do something else (Anaya-Durand \& AnayaHuertas, 2010). The effect produced by positive and negative emotions on intrinsic motivation and extrinsic task motivation was studied by Pekrun (1992).

\section{Intrinsic motivation}

It can be defined as that which comes from the subject himself, who is under his control and can reinforce himself. It is assumed that when you enjoy performing a task, positive intrinsic motivation is induced. Positive emotions that are 
not directly related to the content of the task can also have a positive influence on intrinsic motivation, such as the satisfaction of completing a piece of writing. In contrast, negative emotions can affect intrinsic motivation in two ways (Sung \& Hwang, 2013; Wei et al., 2015). The first consists of negative emotions such as anxiety, anger, sadness, etc., which can reduce the enjoyment of the task. Second, a negative extrinsic motivation opposite to the positive one can appear that leads to the non-execution of the task (avoidance behavior) because it is linked to negative past experiences. Therefore, in addition to preventing positive intrinsic motivation, negative emotions also produce negative intrinsic motivation. One of the negative emotions that leads to non-execution or avoidance is boredom. Negative emotions produce what is known as negative intrinsic motivation and lead to non-execution or avoidance of the task, they can be related not only to the results but also to its content (Lunenberg \& Korthagen, 2003; O’Neill et al., 2018).

\section{Extrinsic motivation}

It is defined as one that comes from outside and that leads to the execution of the task, all kinds of emotions related to results are supposed to influence extrinsic motivation. According to Pekrun (1992), one can distinguish prospects from retrospectives. Where he considers that prospective emotions are those that are immediately and directly linked to the results of the tasks (grades, grades, praise from parents, hope, expectations of enjoyment, anxiety, etc.). Thus, anticipatory enjoyment expectations would produce positive extrinsic motivation, that is, motivation to perform the task to obtain positive results. On the other hand, hopelessness can induce a state of helplessness that entails the reduction or total cancellation of extrinsic motivation in order not to be able to achieve positive results or avoid negative ones. It can be assumed that positive extrinsic motivation contributes effectively (together with positive intrinsic motivation) to total task motivation.

The case is complicated when negative results are related to the extrinsic avoidance motivation produced, for example, by anxiety (Richardson \& Noble, 1983). Two situations can be distinguished to avoid failure and negative results: non-restrictive and restrictive. Ordinary class assignments, as non-restrictive, can lead to success by demanding easier solutions from the student. In restrictive situations, for example, an exam can prevent failure by providing the student with the necessary teaching resources (techniques, skills, etc.) to face them successfully. A student who is intrinsically motivated assumes responsibility for a job or task for his interest, for the pleasure it provides, for the satisfaction he finds in doing it because it is oriented to a well-defined and congruent objective (in this case of learning) with their expectations (Lepper, 1988).

A student may be extrinsically motivated in what he assumes as his responsibility, to obtain some recognition or avoid some punishment or negative consequence, external to the activity itself, for example, a job or task. Motivation is defined by Ames (1992), for learning is an attitude that is characterized by permanent and long-term involvement, committing himself to maintain that attitude for life. It has been found that when students are confronted with complex tasks, those with intrinsic motivation use a problem-solving process with more logical structures and analysis of alternatives. In contrast, extrinsically motivated students prefer a more superficial analysis, adjusting to the essentials required by the teacher. Students with intrinsic motivation prefer to work following a certain degree of challenge to solve them. The extrinsically oriented are inclined to work and problems with a lower degree of difficulty, using the minimum effort necessary to obtain the maximum recognition possible (Lepper, 1988).

There are various theories about motivation based on the individual's needs and their demand responses to them. Within the humanistic theories, one of the most accepted is the one proposed by Maslow (1943), he summarizes in his theory the results of an extensive investigation of human motivation. It proposes a hierarchy of human needs. These have been classified into two groups: Those based on the replacement of deficiencies and those that involve the needs of growth or progress. Regarding the substitution deficiencies, each level must be satisfied before moving up to the next higher-order level. Once each of the levels is corrected, if any deficiency is detected in the future, the individual himself proceeds to eliminate or correct them. The basic principle of Maslow's Theory, called Maslow's Pyramid (Figure 2), proposes that to the extent that the individual becomes more transcendent and fully achieved and takes advantage of their potential. You become wiser and automatically know how to deal with a wide variety of situations. $\mathrm{He}$ is, in short, a fully self-motivated person (Rockich-Winston et al., 2018; Uerz et al., 2018).

Rivas, F. E. C., Pilligua, M. L. B., Guerrero, J. A. A., Moreira, J. A. M., \& Zambrano, M. J. Z. (2021). Processes aimed at students to improve their learning. International Research Journal of Management, IT and Social Sciences, 8(6), 712-719. https://doi.org/10.21744/irjmis.v8n6.1972 


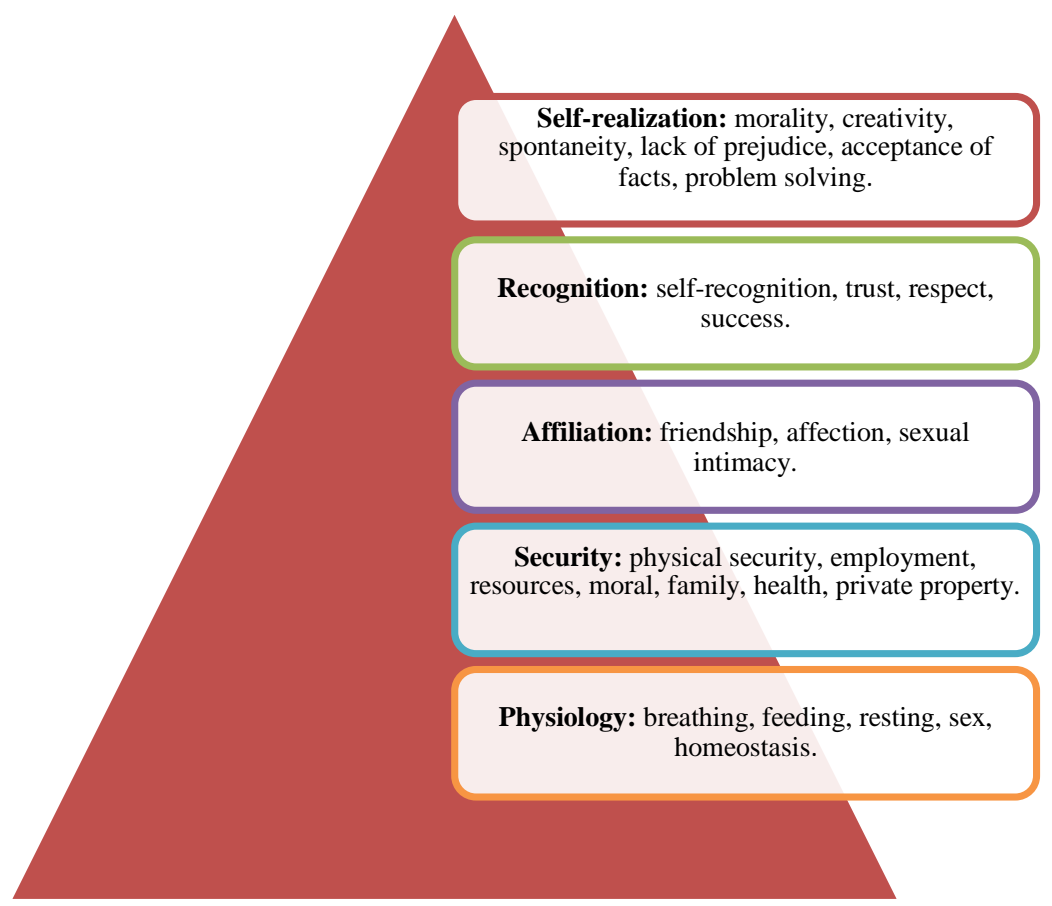

Figure 2. Maslow's pyramid: Hierarchy of needs.

Source: (Maslow, 1943)

Kooker (1976), carried out an experiment analyzing his students' grades before and after the application of a noncompulsory class attendance regime. Grades increased when attendance was not required, however, there was a high attendance rate and better grades. The effect of stress on performance was widely studied by researchers Yerkes \& Dodson (1908), who stated that for efficient behavior to occur, motivation should not be too low or too high. This statement, known as "Yerkes and Dodson's Law" (Figure 3), was confirmed in numerous examples from everyday life and in laboratory investigations carried out with chimpanzees, later confirmed with humans. According to this law, there is a relationship between motivation and stress, and performance.

The behavior is represented as an inverted "U". It is appreciated that both low levels of stress or motivating factors or high levels of it cause poor performance. Notably, there is an optimal value of stress that causes maximum performance in the individual. Based on a wide spectrum of experimental values, it can be seen that both small and very high motivation values result in poor performance. This suggests that too little or too little stimulus can be counterproductive in achieving optimal performance (Fishman et al., 2003; Hwang \& Chang, 2011).

In terms of the teaching-learning process, the teacher must know the optimal "pressure" or requirement towards his students, which allows him an optimal performance in his learning assumption. It is interesting to compare the behavior with the one that occurs in the vaporization phenomenon, where, effectively, there is also an optimum (maximum) in the heat flow, for a given temperature gradient. When the latter is exceeded, there is a decrease in the transmitted heat. There is an optimal value in it. The same goes for stress. A certain necessary value is required that should not be exceeded. The teacher must work in a safe region of the level of demand towards his students, which does not lead to discouragement and low performance. Expectations should be sufficient, but not exaggerated, in such a way as to promote an increase in the achievement of your students (Winne, 2004; Dahalan et al., 2012).

\section{Conclusion}

Motivational processes are very important in the learning process of students to better understand the classes taught by the teacher. Motivation on the part of the teacher is an essential element to improve the adaptation process of the students. Parents or legal representatives must be actively and continuously integrated into the learning process of their children or represented. 
Conflict of interest statement

The authors declared that's they have no competing interests.

Statement of authorship

The authors have a responsibility for the conception and design of the study. The authors have approved the final article.

Acknowledgments

We are grateful to two anonymous reviewers for their valuable comments on the earlier version of this paper.

Rivas, F. E. C., Pilligua, M. L. B., Guerrero, J. A. A., Moreira, J. A. M., \& Zambrano, M. J. Z. (2021). Processes aimed at students to improve their learning. International Research Journal of Management, IT and Social Sciences, 8(6), 712-719. https://doi.org/10.21744/irjmis.v8n6.1972 


\section{References}

Ames, C. (1992). Classrooms: Goals, structures, and student motivation. Journal of educational psychology, 84(3), 261.

Anaya-Durand, A., \& Anaya-Huertas, C. (2010). Motivate to pass or to learn? Learning motivation strategies for students. Technology, science, education, 25 (1), 5-14.

Castro, S., \& de Castro, B. G. (2005). The styles of learning in the education and learning: A proposal for its implementation. Revista de Investigacion, (58), 83-102.

Dahalan, N., Hassan, H., \& Atan, H. (2012). Student engagement in online learning: Learners attitude toward ementoring. Procedia-Social and Behavioral Sciences, 67, 464-475. https://doi.org/10.1016/j.sbspro.2012.11.351

Fishman, B. J., Marx, R. W., Best, S., \& Tal, R. T. (2003). Linking teacher and student learning to improve professional development in systemic reform. Teaching and teacher education, 19(6), 643-658. https://doi.org/10.1016/S0742$051 X(03) 00059-3$

Hwang, G. J., \& Chang, H. F. (2011). A formative assessment-based mobile learning approach to improving the learning attitudes and achievements of students. Computers \& Education, 56(4), 1023-1031. https://doi.org/10.1016/j.compedu.2010.12.002

Kooker, E. W. (1976). Changes in grade distributions associated with changes in class attendance policies. Psychology: A Journal of Human Behavior.

Lepper, M. R. (1988). Motivational considerations in the study of instruction. Cognition and instruction, 5(4), 289309.

Lunenberg, M., \& Korthagen, F. A. (2003). Teacher educators and student-directed learning. Teaching and Teacher education, 19(1), 29-44. https://doi.org/10.1016/S0742-051X(02)00092-6

Maslow, A. H. (1943). A theory of human motivation. Psychological review, 50(4), 370.

O'Neill, R., Shapiro, M., \& Merchant, A. (2018). The role of the operating room in medical student education: differing perspectives of learners and educators. Journal of surgical education, 75(1), 14-28. https://doi.org/10.1016/j.jsurg.2017.06.013

Oka, A. A. (2021). Utilizing digital applications in improving student learning outcomes (review of biology teaching and learning strategies). International Research Journal of Management, IT and Social Sciences, 8(5), 476-486. https://doi.org/10.21744/irjmis.v8n5.1924

Pekrun, R. (1992). The impact of emotions on learning and achievement: Towards a theory of cognitive / motivational mediators. Applied psychology , 41 (4), 359-376.

Portilla Rendón, $\mathrm{AB}$ (2002). The teacher training of university teachers: profile and lines of training . Autonomous University of Barcelona.

Prudente Tomalá, LR (2015). Motivational activities in the learning process of the second-grade language and literature subject of the Cristóbal Colón basic education school, Barcelona Commune, Manglaralto Parish, Santa Elena Canton, Santa Elena Province, school year 2014-2015 (Bachelor's thesis, La Libertad: Península de Santa Elena State University, 2015. Motivational activities in the learning process of the second-grade language and literature subject of the Cristóbal Colón basic education school, Barcelona Commune, Manglaralto Parish, Santa Elena Canton, Province of Santa Elena, school year 2014-2015. La Libertad. UPSE, Matriz. Faculty of Education Sciences and Languages. 119p.).

Richardson, S. A., \& Noble, R. D. (1983). Anxiety: another aspect of problem solving. In AIChE symposium series on problem solving (Vol. 79, No. 228, pp. 28-32).

Rockich-Winston, N., Train, B. C., Rudolph, M. J., \& Gillette, C. (2018). Faculty motivations to use active learning among pharmacy educators. Currents in pharmacy teaching and learning, 10(3), 277-284. https://doi.org/10.1016/j.cptl.2017.11.015

Silva Zambrano, T. I. (2016). Estrategias motivacionales que permitan mejorar la adaptación de los estudiantes en el proceso de enseñanza aprendizaje.

Suhifatullah, M. I., Sutarman, S., \& Thoyib, M. (2021). Character education strategies in improving students' spiritual intelligence. International Research Journal of Management, IT and Social Sciences, 8(2), 155-162. https://doi.org/10.21744/irjmis.v8n2.1350

Sung, H. Y., \& Hwang, G. J. (2013). A collaborative game-based learning approach to improving students' learning performance in science courses. Computers \& education, 63, 43-51. https://doi.org/10.1016/j.compedu.2012.11.019

Tirado, F., Santos, G., \& Tejero-Díez, D. (2013). Motivation as an educational strategy A study in the teaching of botany. Educational Profiles , 35 (139), 79-92. 
Tripiana Muñoz, S. (2016). Motivational strategies during instrumental learning (No. ART-2016-95396).

Uerz, D., Volman, M., \& Kral, M. (2018). Teacher educators' competences in fostering student teachers' proficiency in teaching and learning with technology: An overview of relevant research literature. Teaching and Teacher Education, 70, 12-23. https://doi.org/10.1016/j.tate.2017.11.005

Vite Ríos, CE (2016). Motivation and its effects on the teaching-learning process, in first-year high school students in the subject of accounting processes at the Emigdio Esparza Moreno Educational Unit of the city of Babahoyo, Los Rios Province in the period 2016-2017 ( Bachelor's thesis, Babahoyo: UTB, 2016).

Wei, H. C., Peng, H., \& Chou, C. (2015). Can more interactivity improve learning achievement in an online course? Effects of college students' perception and actual use of a course-management system on their learning achievement. Computers \& Education, 83, 10-21. https://doi.org/10.1016/j.compedu.2014.12.013

Winne, P. H. (2004). Students' calibration of knowledge and learning processes: Implications for designing powerful software learning environments. International Journal of Educational Research, 41(6), 466-488. https://doi.org/10.1016/j.ijer.2005.08.012

Yerkes, R. M., \& Dodson, J. D. (1908). The relation of strength of stimulus to rapidity of habit-formation. Punishment: Issues and experiments, 27-41.

Rivas, F. E. C., Pilligua, M. L. B., Guerrero, J. A. A., Moreira, J. A. M., \& Zambrano, M. J. Z. (2021). Processes aimed at students to improve their learning. International Research Journal of Management, IT and Social Sciences, 8(6), 712-719. https://doi.org/10.21744/irjmis.v8n6.1972 